\title{
Short Report on the Microscopic Examination of Bone Samples from a Neolithic Burial
}

\author{
Michael Schultr
}

\section{Introduction}

Microscopic analysis of archaeological skeletal remains leads both to diagnoses of ancient diseases, and to improved age determinations (e.g., Kerley 1965; Kerley and Ubelaker 1978; Schultz 1986, 2001, 2003; Stout 1992; Wolf 1999). Additionally, changes can be detected at the micro-level which provide insights into pathological conditions resulting from every-day life, such as inactivity atrophy, which macroscopically might not be clearly observable (Schultz 1986, 1997, 2001, 2003). Also, the effects of heat and fire, occurring perimortem or postmortem, produce characteristic changes in the microstructure of bones (Grimm and Strauch 1959; Piepenbrink and Herrmann 1988; Schultz 1986, 1997, 2001, 2003; Teschler-Nicola and Schultz 1984). In the case of small bone fragments, it may not be clear whether they are of human or other animal origin. The histological analysis of bone samples can establish their identity (Harsányi 1978, 1993; Schultz 2001). Furthermore, microscopic examination of ancient bone samples can frequently yield important information as to the state of preservation and the kind of postmortem destruction (e.g., Hackett 1981; Schultz 1986, 1994, 1997, 2001, 2003; Stout and Teitelbaum 1976), necessary for the dating of the archaeological bones by the radiocarbon technique, or for molecular work, for instance, on ancient 
DNA and collagenous and non-collagenous bone proteins (Schmidt-Schultz and Schultz

2004, 2005, 2007), or examination of trace elements and stable isotopes (e.g., Hotz 2002; Schultz 1986, 1997).

Reliable diagnoses are the basis of etiology and epidemiology of diseases in past populations. However, this is not always easy. As a rule, paleopathologists can only examine the vestiges of ancient diseases in dry bones. There are no soft tissues or cells, which play such an important role in pathological investigations on recent materials, which could be studied to establish a reliable diagnosis or for comparative purposes. When archaeological skeletal remains are studied by macroscopy alone or even additionally by radiological techniques, the rate of false diagnoses is still high. Therefore, special methods and techniques, particularly at the microscopic level, need to be established to render such diagnoses more reliable (Schultz 2001, 2003).

Remark: We should keep in mind that the results of the microscopic investigation of two small samples, only a few square centimetres in size from two long bones are not representative enough to characterize the health condition of one individual and certainly not of the whole population.

\section{Materials and Methods}

Two samples which were taken from the burial PCN-IV Skeleton 6 (see Drawatik this volume) (right femur and left humerus) of the Neolithic cemetery of Pacung, northern Bali (Indonesia), were X-rayed and then investigated using low power microscopy and thin ground section microscopy. As archaeological bone might be, as a rule, fragile and extremely brittle, the technique of choice for the microscopic examination is the preparation of undecalcified thin ground sections (e.g., Hackett 1976; Stout 1992; Schultz 1986, 2001, 2003). To produce thin ground sections for light microscopy, a special technique was established based upon the method of plastination developed by Hagens (1979), but modified for histological purposes by Michael Brandt and Michael Schultz working on archaeological specimens (cf. Schultz 1988, 2001). The embedding medium is a special epoxy resin $\left(\right.$ Biodur $\left.^{\circledR}\right)$.

The embedded samples were mounted on a glass slide, cut with a special circular saw (Dr. Steeg and Reuter, Frankfurt am Main) and ground down to a thickness of $70 \mu \mathrm{m}$ and $50 \mu \mathrm{m}$ (unstained thin ground sections examined in plane or polarized light) with the same saw using a special circular disk (cf. Schultz 1988, Schultz and Drommer 1983). Thus, from each sample two sections were available for light microscopic research.

The thin ground sections were examined by transmission microscopy in plane and polarized light using the light microscope DMRXP (Leica). Thus, the nature of possible pathological structures could be relatively easily detected. The use of 
polarized-light microscopy is very useful for examining ground sections produced from dry bone samples to identify collagen fibres and the special pattern of mineralized structures in normal and pathologically changed bones. The use of a hilfsobject red $1^{\text {st }}$ order (quartz) as compensator (cf. Schultz 1988) yields more information on the features of macerated bone and ossified soft tissues because various structures, for instance, collagen fibres in poorly preserved bone structure and their orientation as well as agents and products of diagenesis, such as crystals, and remains of flora and fauna, are better observable (Schultz 1997).

The age of the individuals was checked by the histomorphological and the histomorphometric method (e.g., Kerley 1965; Kerley and Ubelaker 1978; Wolf 1999).

\section{Results}

\section{Taphonomy}

The X-ray images show slight radiopaque spots which suggest diagenetic influences. Therefore, all four thin ground sections were studied for alterations due to diagenesis (taphonomy). The quality of the preservation of the inorganic materials (mineralized structures) of the bony tissue is relatively good (Photos 1a, 1b, 3a, $3 \mathrm{~b}$ ), however, the preservation of the organic materials (e.g., bone collagen fibres) is fair to poor (right femur: Photos 1 and 2) and poor (left humerus: Photo 3).

As a rule, diagenesis occurs in bones after the process of decomposition and is associated with characteristic morphological features of decay.

Sometimes bones might be preserved in the ground by protective surroundings. This did not happen in the case of these two samples. Both samples show relatively advanced diagenetic destruction of their microstructure due to the growth of algae (Photos 1d, 2a-b, 2d, 3c) which led to the partial loss of original organic materials, such as bone collagen. Thus, the skeletons apparently remained over a relatively long time period in muddy or wet earth (e.g., shore of a lake or the sea). However, the process of diagenesis worked slowly and incompletely. In both samples, the algae growth infiltrated the compact bone substance from the external (periosteal) and the internal (endosteal) surfaces (Photos 1c, 3b), as well as from the lumina of the blood vessel canals (Haversian canals: Photos 1d, 2a, 2b, $3 \mathrm{c})$. There is another interesting taphonomic feature. In some blood vessel canals, particularly in the humerus sample and, here, in the central and the endosteal area of the compact bone substance, there is evidence of a circumscribed secondary crystallization process which is characterized by the aggregation of crystals which filled the lumina of the blood vessel canals (Photos 3b, 3c). This phenomenon cannot be mistaken for the beginning of a fossilization process but is due to the reactions between the degradation process of soft tissue remains and the surrounding soil (cf. Schultz 2001). 
Additionally, there is evidence of long lasting soil pressure which caused microfractures (cracks) in the compact bone substance of both samples (Photos 1d, 2b).

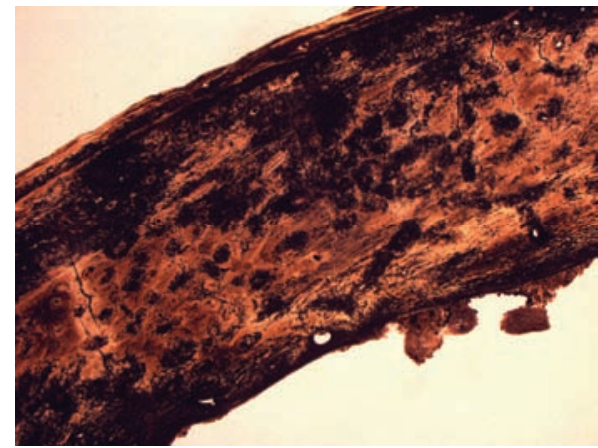

Photo 1a) Bali femur: Overview of the cross section. Undecalcified thin ground sections $(70 \mu \mathrm{m})$ viewed through the microscope in plane transmission light. Magnification 16x.

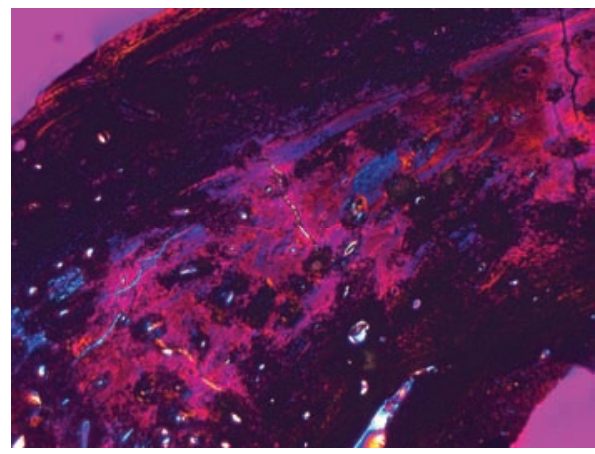

Photo 1c) Bali femur: Close up of the cross section. Region of the external and the internal circumferential lamellae relative severely affected by diagenesis (dark zones). Undecalcified thin ground sections $(70 \mu \mathrm{m})$ viewed through the microscope in polarized transmission light using a hilfsobject red $1^{\text {st }}$ order (quartz) as compensator. Magnification 25x.

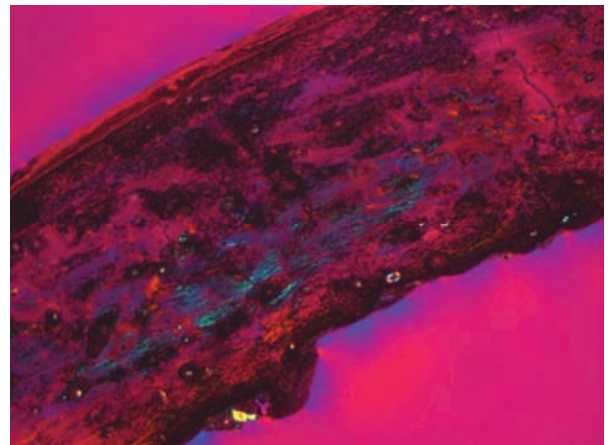

Photo 1b) Bali femur: Overview of the cross section. Undecalcified thin ground sections $(50 \mu \mathrm{m})$ viewed through the microscope in polarized transmission light using a hilfsobject red 1st order (quartz) as compensator. Magnification 16x.

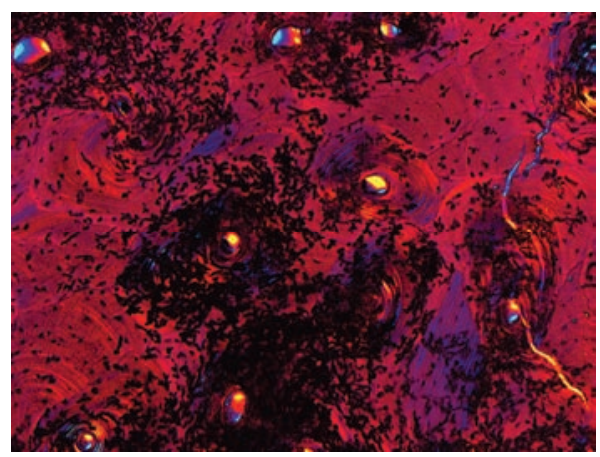

Photo 1d) Bali femur: Haversian systems (osteons) affected by postmortem tunneling due to algae growth (diagenesis). Almost complete loss of collagen fibers. Micro-fractures (cracks) due to postmortem soil pressure. Undecalcified thin ground sections $(50 \mu \mathrm{m})$ viewed through the microscope in polarized transmission light using a hilfsobject red $1^{\text {st }}$ order (quartz) as compensator. Magnification 100x. 


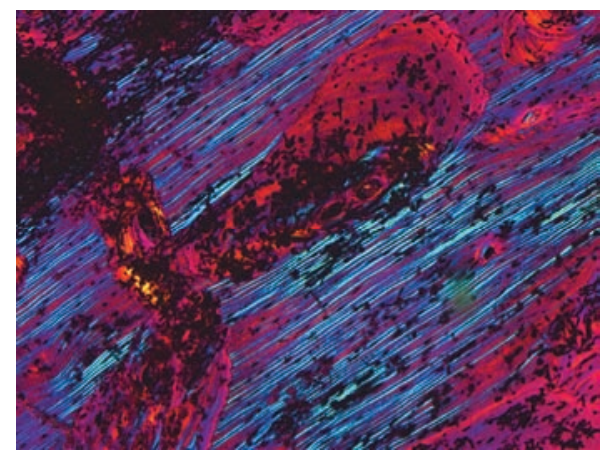

Photo 2a) Bali femur: Individual from burial PCN-IV Skeleton 6. Cross sections through femur sample. Remains of Haversian systems (osteons) and relatively well preserved tangential lamellae. In this area, collagen fibers are relatively well preserved. Undecalcified thin ground sections $(50 \mu \mathrm{m})$ viewed through the microscope in polarized transmission light using a hilfsobject red $1^{\text {st }}$ order (quartz) as compensator. Magnification $100 \mathrm{x}$.

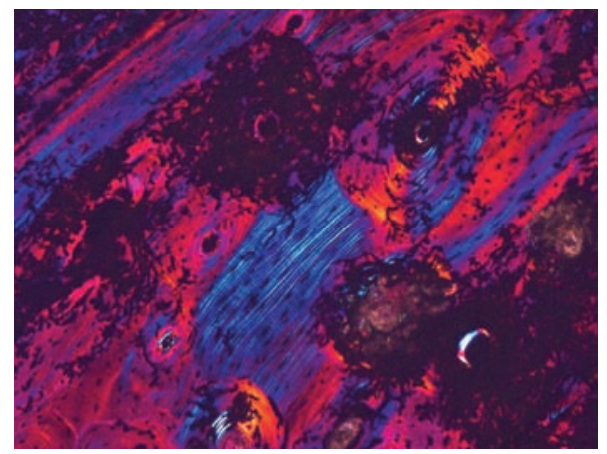

Photo 2c) Bali femur: Relatively well preserved external circumferential lamellae with blood vessel impression. Tunneling due to postmortem algae growth (diagenesis). Undecalcified thin ground sections $(50 \mu \mathrm{m})$ viewed through the microscope in polarized transmission light using a hilfsobject red 1st order (quartz) as compensator. Magnification 100x.

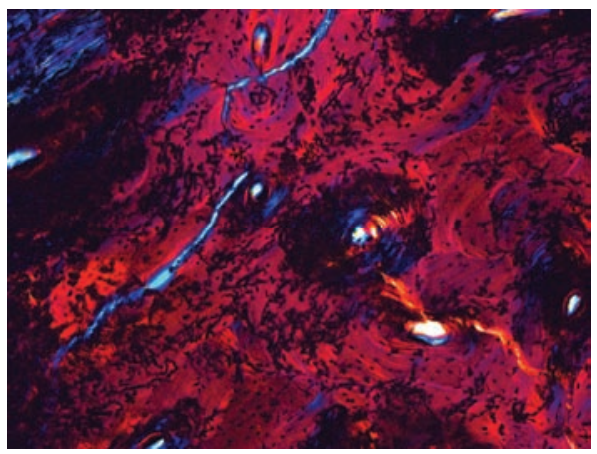

Photo 2b) Bali femur: Haversian systems (osteons) affected by postmortem tunneling due to algae growth (diagenesis). Almost complete loss of collagen fibers. Micro-fractures (cracks) due to postmortem soil pressure. Undecalcified thin ground sections $(70 \mu \mathrm{m})$ viewed through the microscope in polarized transmission light using a hilfsobject red $1^{\text {st }}$ order (quartz) as compensator. Magnification 100x.

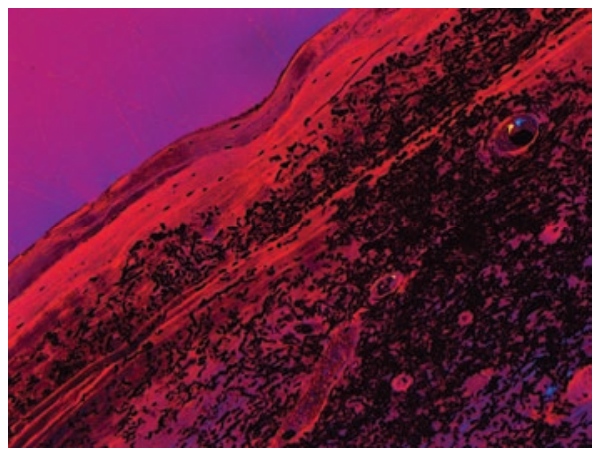

Photo 2d) Bali femur: Haversian systems (osteons) and tangential lamellae partially affected by postmortem tunneling due to algae growth (diagenesis). Undecalcified thin ground sections $(70 \mu \mathrm{m})$ viewed through the microscope in polarized transmission light using a hilfsobject red 1st order (quartz) as compensator. Magnification 100x. 


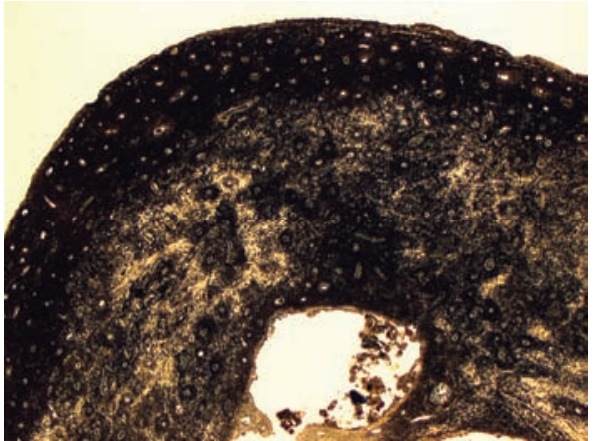

Photo 3a) Bali humerus : Overview of the cross section. Undecalcified thin ground sections $(50 \mu \mathrm{m})$ viewed through the microscope in plane transmission light. Magnification 16x

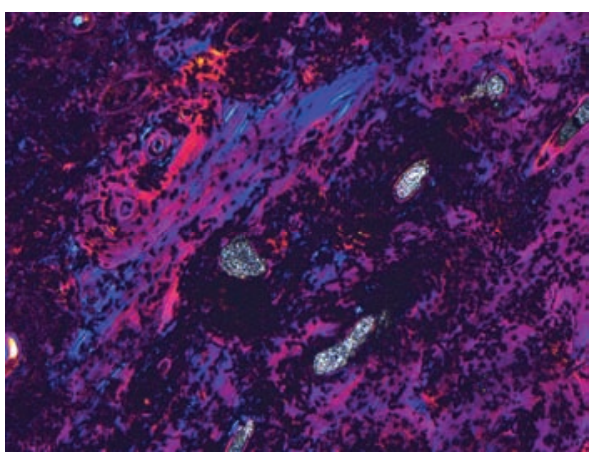

Photo 3c) Bali humerus : Haversian systems (osteons) and remains of tangential lamellae partially severely affected by postmortem tunneling due to algae growth (diagenesis). Crystals in Haversian canals in the middle and the endosteal area of the compact bone substance as product of diagenesis. Undecalcified thin ground sections $(50 \mu \mathrm{m})$ viewed through the microscope in polarized transmission light using a hilfsobject red $1^{\text {st }}$ order (quartz) as compensator. Magnification $100 \mathrm{x}$.

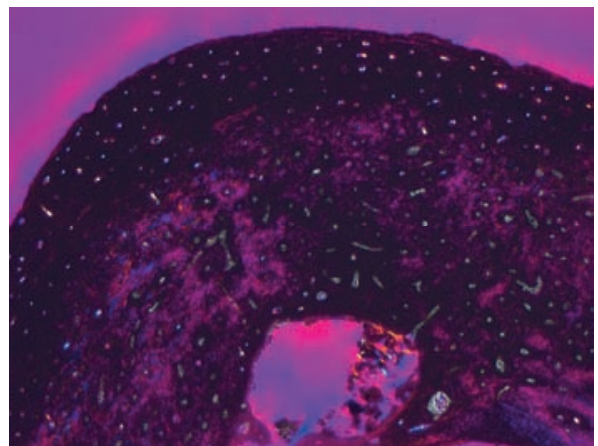

Photo 3b) Bali humerus: Overview of the cross section. Note postmortem crystals in Haversian canals as product of diagenesis. Undecalcified thin ground sections $(50 \mu \mathrm{m})$ viewed through the microscope in polarized transmission light using a hilfsobject red 1st order (quartz) as compensator. Magnification $16 \mathrm{x}$

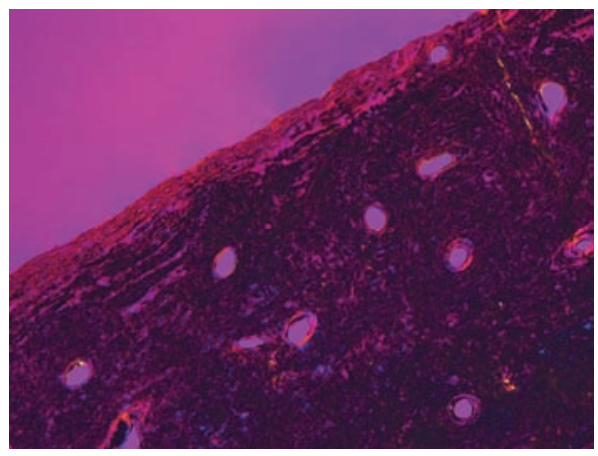

Photo 3d) Bali humerus : Relatively poorly preserved incomplete external circumferential lamellae. Tunneling due to postmortem algae growth (diagenesis). Undecalcified thin ground sections $(50 \mu \mathrm{m})$ viewed through the microscope in polarized transmission light using a hilfsobject red 1 st order (quartz) as compensator. Magnification 100x. 


\section{Microscopic Age Determination}

Using thin ground sections which were produced from samples taken from the two long bone fragments (Photos $1-3$ ), the age at death was estimated by the micro-morphometric and the micro-morphological age determination. Four morphological features were studied: 1) Haversian systems (= osteons), 2) fragmented osteons, and 3) non-Haversian systems, as well as 4) the external and the internal circumferential lamellae. If we start with the most important structure of the compact bone substance which is represented by the osteon or Haversian system, we observe that in both long bone samples most of the osteons show a regular shape and size as well as canals characteristic of individuals of the juvenile or young adult age group (Photos 1d, 2b, 3c). Large sized blood vessel canals or resorption holes which would be characteristic of the mature and senile age groups are missing. The external circumferential lamellae is very well developed. In the sample taken from the femur (Photo 2c), the external circumferential lamellae are better preserved than in the sample taken from the humerus (Photos 3c). The internal circumferential lamellae are not as well developed (Photos 1b, 3b) and in the sample from the humerus not very well preserved.

Thus, the estimated age of the samples from burial PCN-IV S 6 is 15-20 (10) years for the right femur and 15-20 (25) years for the left humerus. Therefore we can assume a core age of 15-20 years for this individual.

\section{Pathology}

Bone surfaces of the two samples representing small fragments of the right femur and left humerus of the individual from burial PCN-IV SK6 were investigated by magnifying glass and a low power binocular microscope. No vestiges of pathological conditions were observed on the external surfaces.

$\mathrm{X}$-ray images did not reveal any pathological conditions.

Despite the relatively poor preservation of the two samples, a microscopic investigation of all four ground sections was carried out to diagnose vestiges of diseases or pathological conditions. There is no evidence of vestiges of systemic deficiency diseases or inflammatory processes.

\section{Summary}

Two long bone samples (femur, humerus) of one individual from the Neolithic site of Pacung in northern Bali (Indonesia) were investigated using macroscopic, low power microscopic, radiological and light microscopic techniques including polarizing microscopy. The age was estimated by histomorphological and histomorphometric age determination to be $15-20$ (10) years (femur) and $15-20$ (25) years (humerus). The compact bone substance of the two samples showed pronounced diagenetic changes mainly due to the growth of algae which had infil- 
trated the compact bone substance from all external and internal surfaces which suggests that the burials had been interred in wet earth. There is influence of mild soil pressure expressed by some micro-fractures. Vestiges of pathological processes were not observed.

\section{Acknowledgments}

The author wishes to thank Michael Brandt and Ingrid Hettwer-Steeger (Department of Anatomy, University of Göttingen, Germany) for preparing the ground sections and Cyrilla Maelicke (Department of Histology, University of Göttingen, Germany) for reading the English text. Furthermore, the author thanks Brigitta Hauser-Schäublin for bone samples from the burial PCN-IV SK6 excavated at Pacung in 2002 and important archaeological information.

\section{References}

Grimm, H. und R. Strauch

1959 Schliffuntersuchungen am Knochen zum Nachweis einer Feuerbehandlung bei der Bestattung. Ausgrabungen und Funde 4: 262-264.

Hackett, C.J.

1976 Diagnostic Criteria of Syphilis, Yaws and Treponarid (Treponematoses) and some other Diseases in Dry Bones. Sitzberichte der Heidelberger Akademie der Wissenschaften, Bd. 4; pp. 1-124. Berlin: Springer.

1981 Microscopical Focal Destruction (Tunnels) in Exhumed Human Bones. Medicine, Science and the Law 21: 234-265.

Hagens, G. v.

1979 Impregnation of Soft Biological Specimens with Thermostetting Resins and Elastomers. The Anatomical Record 194: 247-255.

Harsányi, L.

1978 Unterscheidung von Menschen- und Tierknochen. In: Hunger, H. and D. Leopold (Hg.): Identifikation; pp. 100-112. Leipzig: JA Barth.

1993 Differential Diagnosis of Human and Animal Bone. In: Grupe, G. and A.N. Garland (eds.): Histology of Ancient Human Bone: Methods and Diagnosis; pp. 79-94. Berlin: Springer Verlag:

Hotz, G.

2002 Die Bestattungsplätze des Klosters St. Johann - Anthropologische Auswertung einer frühmittelalterlichen bis neuzeitlichen Skelettserie unter spezieller Berücksichtigung spurenelementanalytischer Fragestellungen. Diss. phil., Universität Basel.

Kerley, E.R.

1965 The Microscopic Determination of Age in Human Bone. American Journal of Physical Anthropology 23: 149-163. 
Kerley, E.R. and D.H. Ubelaker

1978 Revision in the Microscopic Method of Estimating Age at Death in Human Cortical Bone. American Journal of Physical Anthropology 49: 545-546.

Piepenbrink, H. and B. Herrmann

1988 Behandlung überdauerter Weichgewebe. In: Knussmann, R. (Hg.): Anthropologie. Handbuch der vergleichenden Biologie des Menschen, Bd. 1, 1; pp. 571-576. Stuttgart, New York: G. Fischer.

Schmidt-Schultz, T.H. and M. Schultz

2004 Bone Protects Proteins over Thousand of Years: Extraction, Analysis, Interpretation of Extracellular Matrix Proteins in Archaeological Skeletal Remains. American Journal of Physical Anthropology 123: 30-39.

2005 Intact Growth Factors are Conserved in the Extracellular Matrix of Ancient Human Bone and Teeth: a Storehouse for the Study of Human Evolution in Health and Disease. Biolological Chemestry 386: 767-776.

2007 Well Preserved Non-collagenous Extracellular Matrix Proteins in Ancient Bone and Teeth. International Journal of Osteoarchaeology 17: 91-99.

Schultz, M.

1986 Die mikroskopische Untersuchung prähistorischer Skeletfunde. Anwendung und Aussagemöglichkeiten der differentialdiagnostischen Untersuchung in der Paläopathologie. Archäologie und Museum 6. Liestal: Kanton Baselland.

1988 Methoden der Licht- und Elektronenmikroskopie. In: Knussmann, R. (Hg.): Anthropologie. Handbuch der vergleichenden Biologie des Menschen, Bd. 1, 1; pp. 698-730. Stuttgart, New York: G. Fischer.

1994 Ergebnisse mikroskopischer Untersuchungen an archäologischen Skeletfunden. Ein Beitrag zur Paläopathologie. Beiträge zur Archäozoologie und prähistorischen Anthropologie. In: Kokabi, M. and J. Wahl (Hg.): Forschungen und Berichte zur Vor- und Frühgeschichte in Baden-Württemberg, Bd. 53; pp. 107116. Stuttgart: Theiss.

1997 Microscopic Investigation of Excavated Skeletal Remains: A Contribution to Paleopathology and Forensic Medicine. In: Haglund, W.D. and M.H. Sorg (eds.) Forensic Taphonomy. The Postmortem Fate of Human Remains; pp. 201-222. Boca Raton [u.a.]: CRC Press.

2001 Paleohistopathology of Bone: A New Approach to the Study of Ancient Diseases. American Journal of Physical Anthropology 33: 106-147.

2003 Light Microscopic Analysis in Skeletal Paleopathology. In: Ortner, D.J. (ed.): Identification of Pathological Conditions in Human Skeletal Remains; pp. 73-108. Amsterdam [u.a.]: Academic Press, Elsevier Science.

Schultz, M. and R. Drommer

1983 Möglichkeiten der Präparateherstellung aus dem Gesichtsschädelbereich für die makroskopische und mikroskopische Untersuchung unter Verwendung neuer Kunststofftechniken. In: Hoppe, W.G. (Hg.): Fortschritte der Kiefer- und Gesichts-Chirurgie, Bd. 28; pp. 95-97. Experimentelle Mund-Kiefer-GesichtsChirurgie. Mikrochirurgische Eingriffe. Stuttgart, New York: G. Thieme. 
Stout, S.D.

1992 Methods of Determining Age at Death Using Bone Microstructure. In: Saunders, S.R. and M.A. Katzenberg (eds.): Skeletal Biology of Past Peoples. Research Methods; pp. 21-35. New York: Wiley-Liss.

Stout, S.D. and S.L. Teitelbaum

1976 Histological Analysis of Undecalcified Thin Sections of Archaeological Bone. American Journal of Physical Anthropology 44: 263-70.

Teschler-Nicola, M. and M. Schultz

1984 Jungneolithische Skelette der Badener Kultur aus Leobersdorf und Lichtenwörth, Niederösterreich. Annalen des Naturhistorischen Museums Wien, Bd. 86; pp. 111-144. Wien.

Wolf, M.

1999 Ergebnisse makro- und mikroskopischer Untersuchungen an den römischen Brandgräbern von Rheinzabern (Rheinland-Pfalz). In: Schultz, M. (Hg.): Beiträge zur Paläopathologie, Bd. 3. Göttingen: Cuvillier Verlag. 